\title{
The Right to Social and International Order on the Example of the Activities of the United Nations
}

\begin{abstract}
The subject of the article are the reflections on the right to social and international order on the example of the activities of the United Nations. The United Nations has passed many human rights acts, such as declarations and legally binding laws. The conclusion is that, the unquestionable achievement of the United Nations is the adoption of a large number of legal acts, which guarantee the social and international order. In spite of it, there are no effective mechanisms to guarantee these rights and to seek justice on the international forum.
\end{abstract}

Key words: United Nations, Universal Declaration of Human Rights, human rights, international criminal justice

\section{Introduction}

O ne of the first ventures undertaken by the United Nations Organisation was to prepare a document which would comprise all human rights and freedoms. The Economic and Social Council (ECOSOC) by virtue of the article 68 of the United Nations Charter (United Nations Charter, 1945) established the Commission on Human Rights. Its members included the Chinese philosopher, playwright and diplomat Chang Pengchun, French laureate of the Nobel Peace Prize René Cassin, philosopher Charles Malik and Eleanor Roosevelt (Glendon, 2001). On December 10, 1948, the General Assembly of the United Nations (the UN General Assembly) passed the Universal Declaration of Human Rights with its Article 28 being of utmost importance: "Everyone is entitled to a social and international order in which the rights and freedoms set forth in this Declaration can be fully realised" (Universal Declaration, 1948).

The aim of this study is to examine whether and to what extent, from the perspective of almost seventy years, the international system of human rights protection is able to uphold the rights and freedoms comprised in the Declaration of Human Rights. The study is an attempt to characterise, in view of norms and implementation, the universal system of human rights protection whose function is to create such mechanisms due to which the rights and freedoms expressed in the Declaration would be protected. The author analyses selected UN legal acts which to bigger or lesser degree fulfill the essence of the Article 28. The article is based on the assumption that the unquestionable achievement of the UN is the adoption of a large number of legal acts to guarantee the right to social and international order, but there are no effective mechanisms to guarantee these rights and to pursue justice internationally. In order to verify the assumed hypothesis, a method of system analysis allowing for the explication of the system of human rights 
protection within the UN, as well as institutional and legal analysis that allowed scrutinising legal acts, were used. The method of historical analysis was used to present the origin of the Declaration of Human Rights. In the literature on the subject there are many publications that address issues related to the Universal Declaration of Human Rights, from document collections to scientific studies (Alredsson, Eide, 1999; Darraj, 2010; Morsink, 2017; Schabas, 2013; Sweet, 2003).

\section{"The Bible of Human Rights"}

The UN is the only international organization of global and universal character and the human rights sector is an important aspect of its activities. The Declaration of Human Rights was a milestone on the way to forming the universal system of human rights protection. None of the states voting in the United Nations was against it, whereas the representatives of eight countries abstained. Asian and African colonies did not send their representations, but in course of the decolonisation process they signed and ratified the Declaration.

As noted by Roman Kuźniar, the Declaration of Human Rights is a synthesis of various legal schools and a compromise as to the definition or catalog of different legal entities. The aforementioned synthesis and compromise were preceded by the disclosure, at the very beginning of the negotiations, of differences between individual schools and doctrines. The most important was the dispute between the doctrine of natural law and legal positivism. It concerned mainly the appeal to God proposed by some countries in the preamble. In this case, the positivist standpoint which states that the rights, especially in the international document, are determined by the states, won. There was also a dispute between the liberal western countries and communist states. The differences between "the West" and "rest of the world" were also apparent (Kuźniar, 2008, pp. 65-66).

An important element of the Declaration of Human Rights is the principle of equality and non-discrimination. The Declaration distinguishes several categories of rights and freedoms: fundamental, civic, political, economic and social. Fundamental rights include the right to life; the right to liberty and personal security; the prohibition of slavery; prohibition of torture and other degrading treatment or punishment; the right of every person to recognize his/her legal personality; the right to equality before the law; the right to appeal against the acts violating the rights; the right to a just, independent and impartial trial; the right to privacy; prohibition of arbitrary arrest, detention or exile from the country. Civic rights include the right to leave and return to your own country; the right to asylum; the right to citizenship; the right to marry and start a family; the right of every person to own property, freedom of thought, conscience and religion. Political rights include the right to have and express opinion, including the search, reception and dissemination of information and views by all means, regardless of boundaries, the right to peaceful gathering and association, the right to participate in public life. The catalog of social and economic rights includes the right to social insurance, the right to work, the protection of working conditions, adequate remuneration, the creation of trade unions, the right to furlough and rest, the right to an adequate standard of living (including health 
care), the right to free, universal and compulsory education at least at a basic level; the right to participate in cultural life (Universal Declaration, 1948).

The document did not contain the right to resist (except for a brief mention in the preamble) and the right to individual complaint. As noted by Wiktor Osiatyński, a surprising feature of the Declaration was the complete lack of minority rights. It is all the more strange that great importance was attached to this issue already in the interwar periodby the League of Nations. The collapse of this system took place in the face of Nazi crimes during World War II - the countries of Central and Eastern Europe absolutely rejected the idea of granting collective rights to the Germans or any other minority. In the new system of human rights, minorities were to be protected only as individuals (Osiatyński, 2011, p. 51).

The Universal Declaration of Human Rights was not passed as a binding international treaty. It was to constitute a kind of moral code and to set priorities and directions of development in the area of human rights. The Declaration does not contain intentions only, but also state obligations, however without sanctions of international law.

\section{The Main Organs of the United Nations and the Protection of Human Rights}

Article 13 of the Charter of the United Nations mentions that the United Nations General Assembly is to play an important role in the implementation of human rights and fundamental freedoms. Specialized committees have been established within the framework of the UN General Assembly, of which the Committee for Social, Humanitarian and Cultural Issues deals with human rights. It adopts resolutions that are then accepted at plenary meetings of the General Assembly. The General Assembly may appoint subsidiary bodies to perform specific tasks. The Economic and Social Council deals with the coordination of many specialized UN agencies and programs. It indirectly affects the activity of states, intergovernmental and non-governmental organizations active in the field of human rights (United Nations Charter, 1945). It deals with the preparation of documents, convening conferences, issuing recommendations for the states, the UN bodies and other organizations, and cooperation with them. Pursuant to art. 71 of the UN Charter and Resolution of the Economic and Social Council (ECOSOC) No. 1296 from 1968 the UN may cooperate with non-governmental organizations (Resolution, 1968). Commissions (Social Development, Women's Status, Prevention of Crime and Criminal Justice, Human Rights) and committees that directly or indirectly deal with the broadly understood human rights issues function within ECOSOC.

The aforementioned Human Rights Commission is an intergovernmental body whose members were chosen by the General Assembly of the UN according to a geographical key. It dealt with the development of conventions, submitted reports and recommendations to ECOSOC, appointed experts, rapporteurs and working groups. In 1966, the General Assembly of the UN adopted a resolution calling on the Economic and Social Council and the Human Rights Commission to develop for the United Nations standards preventing violations of human rights. This led to the development of certain schemes consisting in urging states to act in accordance with accepted norms. However, they have a weak legal basis. 
By virtue of the Resolution 1235 (XLII) of 1967, ECOSOC mandated the Human Rights Commission to analyse cases of mass violations of human rights and to submit reports and recommendations to ECOSOC (Resolution, 1967). Mass and systematic violations of human rights were the subject of Resolution No. 1503 (XLVIII) of 1970. Pursuant to this resolution the UN authorities are obliged to take actions aimed at ending human rights violation. The only attribute of this procedure is its confidentiality and the fact that both ECOSOC and the UN General Assembly could only condemn the country (Resolution, 1970). It is only since 1978 that it has become possible to make the name of the state whose case is being considered public. Resolution 1235 offered some options for a faster procedure in the event of mass violations of human rights. The Commission could consider the cases without participation of the Subcommittee and working groups. In addition, the procedure was open. A lot of emotions were raised by the annual sessions of the Human Rights Committee, in which representatives of the observer countries and non-governmental organizations participated alongside the representatives of $53 \mathrm{Mem}$ ber States. Coalitions were formed for resolutions condemning the governments of some countries for violations of human rights. Nevertheless, the Commission was criticized for its poor effectiveness. The attempt to reform the Commission's mechanisms in 1999 ended with a counterpunch on the part of representatives of countries concerned with the increase of the UN's effectiveness in this area (Rehman, 2010, pp. 53-54).

The United Nations High Commissioner for Human Rights, sited in Geneva, started his activities under the UN General Assembly resolution of 1993 . He is the deputy secretary general and the highest official in the UN structures responsible for the protection of human rights. The first commissioner was Ecuadorian Jose Ayala Lasso. The task of the commissioner is to promote international cooperation in the area of human rights protection; strengthening the implementation of commitments in this field; reaction to the most serious violations of human rights; assistance to countries conducting the democratization process. A relatively new form of the UN activity was its technical and advisory support as well as engagement in local humanitarian operations. It developed in the wake of conflicts in Africa and the former Yugoslavia. Actions coordinated by the Office of the High Commissioner with the consent of the countries in which they are conducted consist in monitoring the observance of human rights in emergency situations and technical assistance for governments in this area (Scheffer, 2012, p. 461).

On March 15, 2006, the Human Rights Council was established. It was the subsidiary body of the UN General Assembly which replaced the Human Rights Commission. The Commission's demise was largely due to the politicisation that increasingly dominated its proceedings and impacted upon its work. Politicisation, that is pursuit of States' national agendas or regional groups' common objectives, took the form of selectivity, partiality and bias. one key example of the impact of politicisation was the Commission's failure to address many gross and systemic country-specific human rights violations whilst simultaneously devoting vastly disproportionate attention to other situations (Freedman, 2011, p. 289).

The Council consists of 47 representatives, it is convened at least three times a year for sessions lasting a minimum of ten weeks. The Council's task is to promote education in the field of human rights; providing technical assistance in consultation with the Member States; presenting recommendations of the UN General Assembly; carrying out 
comprehensive periodic reviews regarding the fulfillment by States of obligations related to the observance of human rights; developing recommendations based on periodic reviews; responding to extraordinary situations of human rights violations; working in cooperation with governments and organizations dealing with human rights; submitting annual reports on the UN General Assembly forum (Resolution, 2006).

The United Nations Human Rights Council was created in 2006 to universally protect and promote human rights. Failures of the Council's predecessor, the Human Rights Commission, had been attributed to politicisation and bias. In order to overcome these and other Commission failings, two new mechanisms were created to assist the new body with fulfilling its mandate. Universal Periodic Review provides a mechanism for examining the human rights records of all UN Member States during a four year cycle. Special Sessions enable the Council to deal with grave human rights crises as they occur. However, these mechanisms have been used by States and regional groups to achieve political aims (Freedman, 2011, p. 290). Simon Hug and Richard Lukács state that the Human Rights Council is being criticized. controversial resolutions are introduced by countries with contaminated human rights acts and that in voting on these resolutions Council members belonging to the European Union (EU) vote very clearly from other members. In addition, EU Member States are almost systematically in minority in these votes (Hug, Lukács, 2014, pp. 83-106; Chilton, Golan-Vilella, 2016, pp. 7-15).

\section{The Covenants of Human Rights}

The problem faced by the system of human rights protection within the UN is its lack of appropriate mechanisms that would minimize human rights violations and allow the persons responsible for violations of these rights to be brought to justice. Extremely important documents are Human Rights Records adopted by the UN General Assembly on December 16, 1966. They were a peculiar compromise, had been announced twenty years earlier, and came into force only in 1976 as the documents had to be ratified by representatives of 35 countries.

The International Covenant on Civil and Political Rights, unlike the Universal Declaration of Human Rights, is a binding international law. The States Parties to the Covenant are required to submit reports every five years on the measures that have been undertaken in order to implement these laws. These reports are examined by the Human Rights Committee based in Geneva. An open consideration of a report lasts up to two days and consists in listening to the explanations of the representatives of a given state and the so-called counter reports of non-governmental organizations. The Committee's final comments are forwarded to the states and in some cases to ECOSOC or the General Assembly of UN. Another mechanism of control is the possibility of lodging a state complaint. This is possible if the state by way of a separate declaration accepts the competence of the Committee to deal with such complaints. The subject of the complaint are violations of human rights and both the complaining and the defendant state must recognize the competence of the Committee. The third mechanism is an individual complaint. It is included in the Optional Protocol to the ICCPR. The States that have joined the Protocol have recognized the Committee's competence to receive and investigate individual 
complaints from people who consider themselves victims of human rights violations in the country that is a party to the Protocol. A complaint may be filed on condition that all possibilities of appeal that exist in internal law have been exhausted, the case cannot be dealt with by another international institution, the petition cannot be anonymous, it must also concern matters that the covenant guarantees. Upon reception of the complaint, the Committee shall turn to the country to which it relates. The state has six months to explain what measures have been taken in connection with the subject of the complaint. The Committee informs the state and the complaining party of its findings. States Parties accept in principle the Committee's findings (International Covenant on Civil, 1966). In 1989, the General Assembly of the UN adopted the Second Optional Protocol to the ICCPR aimed at abolishing the death penalty (The Second, 1989).

At the same time, the International Covenant on Economic, Social and Cultural Rights (ICESCR) was adopted. It is worth noting that the formulations that it contains are far-reaching, but unlike the ICCPR, the control system is very modest. The rights are to be implemented gradually, according to the possibilities available and developed by States. The covenant provided for reporting to the UN Secretary General on the measures taken and the progress made in the area of the rights recognized in ICESCR (International Covenant on Economic, 1966).

In 1987, the Committee on Economic, Social and Cultural Rights began its work. It examines state reports submitted every five years. The debate on the report during which government representatives are asked questions by members of the Committee lasts two days. Representatives of non-governmental organizations also present their position. At the end, the Committee formulates conclusions, suggestions and recommendations as well as general comments on the implementation of the provisions of the Covenant by individual states (Welling, 2008, pp. 933-958).

\section{Selected Documents of the United Nations}

In December 1965, the UN General Assembly adopted the International Convention on the Elimination of All Forms of Racial Discrimination. This is one of the most important legal and international documents for the protection of human rights. In addition to condemning all forms of discrimination, States Parties to the Convention committed themselves to pursuing a policy aimed at eliminating discrimination. A Committee on the Elimination of Racial Discrimination was set up. The Committee's task is to consider reports on measures taken by states to implement the provisions of the Convention. The convention also provides for the possibility of lodging a state complaint. In order for the complaint to be possible, the state must make an additional declaration on this matter independently of the Convention. Disputes related to the interpretation of the provisions of the Convention may be unilaterally delegated to the International Court of Justice (International Convention, 1965).

Anna Spain Bradley believes that the international human rights movement has helped create a world inwhich slavery, genocide, apartheid, and segregation are repudiated and,with the adoption of ICERD, racial discrimination is prohibited. Together,these milestones move the dream of universal human rights closer to reality. However, racism 
remains a barbaric and pervasive truth for too many peo-ple and is the underacknowledged human rights violation of our day. Inresponse, nations must recommit themselves to upholding international le-gal obligations to prevent racial discrimination and to undertaking mean-ingful measures to promote equality and dignity. Nonetheless, combatingracism requires something more. International human rights institutionsand nations alike must acknowledge the deeper problems embedded in ra-cism, including the use of race as a means for categorizing humans, racialideology that promotes racial supremacy, and racial bias. Naming the chal-lenge as human rights racism aims to illuminate the depth of the problemand to reveal the ways that international human rights law is not raciallyneutral. Just as societies and communities continue to grapple with under-standing and ending racism, the places and spaces that promote humanrights must do the same. If it is to be true that all people are equal indignity and rights, we must not shy away from the hard and often uncom-fortable work of addressing racism by its name (Spain Bradley, 2019, pp. 1-58).

In November 1973, the UN General Assembly adopted the International Convention on Suppression and Punishment the Crime of Apartheid. The convention recognized apartheid as a crime in the face of international law and a crime against humanity. The Commission for Human Rights supervised compliance with the provisions. It was authorized to compile lists of people, organizations, institutions and representatives of states who are suspected of committing the crime of apartheid (The International Convention, 1973).

In December 1979, the UN General Assembly adopted the Convention on the Elimination of All Forms of Discrimination against Women (Convention, 1979). The convention established a system of periodic reports considered by the Committee. It is possible to submit disputes in this matter to the International Court of Justice. The Committee analyses government reports and makes suggestions and recommendations in matters that raise its reservations, but also adopts general recommendations, addressed to all governments, regarding the interpretation of specific provisions of the Convention. In October 1999, the UN General Assembly adopted an Optional Protocol allowing the Committee to submit and examine individual complaints. It came into force in December 2000 (The Optional, 1999).

On November 20, 1989 the UN General Assembly adopted the Convention on the Rights of the Child. A Children's Rights Committee was established. States Parties are required to submit relevant reports every five years. The United Nations Children's Fund and other agencies specialising in the United Nations may participate in the procedure of examining reports. At the end of the debate on the report, during which members of the Committee try to identify all weaknesses and infringements in the application of the Convention, the Committee formulates conclusions, suggestions and recommendations for the government (Convention, 1989). Due to the weakness of the control procedure, it is considered that the convention is rather a program declaration. Walter $\mathrm{H}$. Bennett was skeptical about the protection of children's rights at international level. In his opinion, children are the most vulnerable people in the world, there is an understandable desire to embrace them with the widest possible level of protection. This approach may be appropriate in a national text where social mores are widespread, there is a common understanding of standards and language, and mechanisms and resources for law enforcement 
are available. However, this is an uncertain undertaking on the international stage, where standards and resources are very diverse, and strengthening mechanisms are either uncertain or non-existent (Bennett Jr., 1987, pp. 15-30).

In December 1984, the UN General Assembly adopted the Convention against Torture and Other Cruel, Inhuman or Degrading Treatment or Punishment, which came into forcein 1987. The Convention provides for optional possibility (a separate declaration of the State Party is required) for lodging a state and individual complaint, regardless of the obligation for States to submit relevant reports. The controlling body is the Committee against Torture. It consists of ten experts who perform their functions on their own behalf. The Committee is equipped with the right to collect information in the event of learning about the use of torture in one of the States Parties to the Convention. The entire procedure is confidential. Disputes between states regarding the application and interpretation of the Convention may be handed over by either party to the ICJ (Convention, 1984). In the spring of 2002, Optional Protocol was adopted during one of the sessions of the Human Rights Committee (Optional Protocol, 2002).

As David Weissbrodt and Cheryl Heilman note, the difficulty is to define "torture" and "other inhuman treatment or punishment." It states that there is rich and widespread international jurisprudence regarding standards determining whether interrogation methods and conditions of imprisonment constitute torture or cruel, inhuman, humiliating treatment. The Torture Convention was in many cases instigated by various international bodies that did not decide whether the proceedings would lead to a level of torture (Weissbrodt, Heilman, 2011, pp. 343-393).

In Steven Greer's view, the main axiom of international human rights law is that the prohibition of abuse, cruel, inhuman and degrading treatment is absolute in the sense that no exception can be accepted, defended, justified or tolerated under any circumstances. However, for many reasons this is very problematic. The prohibition of torture, cruel, inhuman and degrading treatment in international human rights law can therefore, at best, be "practically" and not absolutely absolute. In other words, this applies to everyone except the rarest circumstances, but, as wisdom maintains, does not rule out any possible justification, dismissal, justification or mitigation (Greer, 2015, p. 101).

\section{International criminal justice}

In the context of the admissibility of individual complaints, the evolution of international criminal justice and the emergence of tribunals allowing individual perpetrators to be brought to justice are of utmost importace. It was a milestone in transferring responsibility from states to individuals.

Since 1946, the United Nations has undertaken procedures aiming at the prevention and punishment of the crime of genocide. In December 1948, the General Assembly of the UN adopted a convention recognizing genocide as a crime in the face of international law. The document also defines the concept of genocide. The States Parties to the Convention assumed the obligation to introduce in their own legislation legal provisions necessary for the implementation of the Convention. Judgment of acts or persons was to take place in front of the tribunal of the state in whose territory the act was committed 
or in front of an international criminal court. The Convention did not create effective mechanisms to properly enforce its provisions (Convention, 1948). The UN General Assembly accepted in November 1968 the Convention on non-applicability of statutory limitations in case of war crimes and crimes against humanity (Convention, 1968).

At the request of the Secretary General, who in turn referred to Chapter VII of the UN Charter, the International Criminal Tribunal for the former Yugoslavia - ICTY (Security Council, 1993) and the International Criminal Tribunal for Rwanda (Security Council, 1994), were created. The ICTY was established on May 25, 1993, as a means to serve the UN Security Council to resolve a bloody conflict in the Balkans. On the other hand, the conflict in Rwanda was the result of many religious and tribal disagreements between the tribes of Tutsi and Hutus in 1990-1994, which could not be resolved by the UN reconciliation forces. In this situation, on November 8, 1995, the Security Council issued Resolution 955 establishing the ICTR. The resolutions were justified by the need to immediately counteract crimes committed and to terminate the conflicts. The legal basis for the appointment of both tribunals has made them temporary, acting on the basis of the principle of superiority in relation to national courts. They judged perpetrators of war crimes, crimes against humanity and genocide. The allegations that arose concerned selective justice and the delay in appointment of such tribunals. It posed the risk of losing evidence and hiding of the perpetrators. However, they constituted an important step on the way to the establishment of the International Criminal Court (Novak, 2015, pp. 13-15).

On 17 July 1998 at the end of the Diplomatic Plenipotentiary Conference at the headquarters of the Food and Agriculture Organisation of the United Nations, the Rome Statute of the International Criminal Court - ICC (Rome Statute, 1998) - the first permanent international court with universal jurisdiction - was adopted. It was an important event, because for many years the international community had not been able to work out mechanisms that would bring to justice people who violate human rights. The Statute has the character of an international treaty and the states participated in the process of its negotiation, adoption and ratification. Already in April 2002, the signatures under the statute reached the required number. It came into force on March 11, 2003 (Schabas, 2011).

The Court consists of: the Presidency, the Judicial Divisions - Pre-Trial Chamber, Trial Chamber, Appeals Chamber - the Office of the Prosecutor and the Registry. The Chambers fulfill the judicial function within particular divisions. The Judicial Divisions consist of eighteen judges who specialize in criminal law and its procedures, and have relevant experience in criminal proceedings. Judges are also required to demonstrate broad competence in relevant areas of international law, such as international humanitarian law and human rights. The composition of the Court's Judicial Divisions must be fully balanced and international, therefore the selection of judges will be determined by criteria such as: representative participation of the main legal systems in the world, fair geographical representation and balanced participation of women and men. The judges are chosen by the Assembly of States Parties. The ICC has a wide catalog of sanctions: the penalty of life imprisonment, imprisonment of up to thirty years, fine and forfeiture of objects coming from crime. The Tribunal is to judge crimes of genocide, war crimes, crimes against humanity and aggression. The definitions of the crimes were presented, only in the case of the crime of aggression it was impossible. The Court is character- 
ized by the principle of complementarity, i.e. the priority is the primacy of national law. If the states show a will to prosecute or are able to conduct proceedings and bring the perpetrators to justice, the ICC is deprived of the opportunity to act. It works basing on the possibility of a complaint, so it is not possible to prosecute ex officio. Neither state nor legal persons, but only natural persons, regardless of citizenship, place of crime and functions. are subject to its competences. None of the state functions exempts from criminal responsibility, which means that the persons in power may be prosecuted - this is the principle of irrelevance of the public function of the accused. The Tribunal is a body independent of the United Nations and has international legal personality. The right to initiate proceedings was received by States Parties, the Security Council and the Prosecutor (Rome Statute, 1998).

Kirsten Ainley thinks that Defenders of the Court suggest it has had a positive impact because: it has accelerated moves away from politics and towards ethics in international relations; it goes a longway towards ending impunity; it is a significant improvement on the previous system of ad hoc tribunals; it has positive spill-over effects onto domestic criminal systems; and because the courage of the Prosecutor and Trial Judges has helped to establish the Court as a force to be reckoned with. Opponents of the Court see it as mired in power politics, too reliant on the United Nations Security Council and on state power to be truly independent; failing to bring peace and perhaps even encouraging conflict; and starting to resemble aneo-colonial project rather than animpartial organ of justice. The verdict on the Court is mixed. It has gone some way to ending impunity and it is certainly an improvement on the ad hoc tribunals. However it is inevitably a political body rather than a purely legal institution, its use as a deterrent is as yet unproven and the expectation that it can bring peace as well as justice is unrealistic (Ainley, 2011, p. 309).

While the International Criminal Court strives for justice for atrocity crimes throughout the world, increasingly, its legitimacy is undermined: powerful states refuse to join, African states prepare to leave, victims do not feel their needs for justice are met (de Hoon, 2017, p. 581).

\section{Conclusion}

"Everyone is entitled to a social and international order in which the rights and freedoms set forth in this Declaration can be fully realised" - this article of the Universal Declaration of Human Rights in the context of the system of human rights protection within the UN is a very complex problem. On the one hand, the provisions of subsequent legal acts passed by the UN include all rights and freedoms, which the UDHR puts emphasis on. It is certainly a great achievement of the $\mathrm{UN}$ to bring about the adoption of so many conventions and treaties regarding human rights. Particularly, given the number of nearly two hundred Member States, the development of any consensus is extremely difficult. However, this does not justify a long period of works on individual documents. For example, since the beginning of works on Human Rights Covenants, it took almost 30 years to put them into force. On the other hand, there are no effective mechanisms to guarantee these rights and to seek justice on the international forum. Especially, the post1989 period has shown the order in which the necessary reforms of the human rights 
protection system were implemented by the UN. It was during the post-Cold War twenty years that we faced numerous ethno-political conflicts in Africa, the Balkans and the Caucasus, with which the international community was unable to cope. Rwanda and Srebrenica are the most illustrative examples of the UN's powerlessness in this matter. The use of a geographical key when filling the most important bodies dealing with human rights has led to a paradoxical situation in which representatives of states notoriously violating human rights and freedoms sat in the Human Rights Commission. The metamorphosis of the Commission into the Human Rights Council has not changed much. One of the advantages of the human rights protection system within the UN are state reports (in the case of treaties under which committees operate). However, these reports are often one-sided, not passed on to the committees on time, and recommendations of committees are not carried out by the states.

Despite the undoubted success of the very fact of establishing the International Criminal Court, war crimes and genocide still occur in various parts of the world. This does not change the fact that one should strive to create standards in the future, by which national courts will be able to judge the perpetrators of human rights violations. The system on which the criminal tribunals operate is not perfect. It must be de-politicised, and goodwill on the part of states is also necessary. An indispensable condition is to revise the statute and submit to the jurisdiction of the Court more countries, including those most powerful like the US and China, so that it becomes a real international criminal court.

Generally, in comparison to the regional system of human rights protection created by the Council of Europe, the UN system has many shortcomings. This system lacks even a document such as the Convention on Human Rights and Fundamental Freedoms, which creates more effective mechanisms. This primarily applies to the judicature of the Court of Human Rights in Strasbourg which has been largely taken into account by other states in the process of lawmaking, such as the application of the law.

\section{Bibliography}

Ainley K. (2011), The International Criminal Court on Trial, "Cambridge Review of International Affairs", vol. 24.

Alfredsson G., Eide A. (eds.) (1999), The Universal Declaration of Human Rights. A Common Standard of Achievement, Martinus Nijhof Publishers, The Hague-Boston-London.

Bennett Jr. W. H. (1987), A Critique of the Emerging Convention on the Rights of the Child, "Cornell International Law Journal" vol. 20, Issue 1.

Chilton A. S., Golan-Vilella R. (2016), Did the Creation of the United Nations Human Rights Council Produce a Better "Jury"?, "Harvard International Law Journal", vol. 58.

Convention against Torture and Other Cruel, Inhuman or Degrading Treatment or Punishment (1984), General Assembly of the United Nations, https://treaties.un.org/pages/ViewDetails. aspx? src $=$ TREATY\&mtdsg_no=IV-9\&chapter $=4 \&$ clang=_en.

Convention on the Elimination of All Forms of Discrimination against Women (1979), General Assembly of the United Nations, https://treaties.un.org/pages/ViewDetails.aspx?src=TREATY\&mtdsg_ no $=$ IV-8\&chapter $=4 \&$ clang=_en.

Convention on the Non-applicability of Statutory Limitations to War Crimes and Crimes Against Humanity (1968), General Assembly of the United Nations, https://treaties.un.org/pages/ViewDetails.aspx?src=TREATY\&mtdsg_no=IV-6\&chapter=4\&lang=en. 
Convention on the Prevention and Punishment of the Crime of Genocide (1948), General Assembly of the United Nations, https://treaties.un.org/pages/ViewDetails.aspx?src=TREATY\&mtdsg no $=$ IV- $1 \&$ chapter $=4 \&$ clang $=$ en.

Convention on the Rights of the Child (1989), General Assembly of the United Nations, https://treaties.un.org/Pages/ViewDetails.aspx?src=TREATY\&mtdsg_no=IV-11\&chapter=4\&clang=_en.

Darraj S. M. (2010), The Universal Declaration of Human Rights, Infobase Publishing, New York.

de Hoon M. (2017), The Future of the International Criminal Court. On Critique, Legalism and Strengthening the icc's Legitimacy, "International Criminal Law Review", vol. 17.

Freedman R., New mechanism of the UN Human Rights Council, "Netherlands Quarterly of Human Rights" vol. 29.

Glendon M. A (2011), A World Made New. Eleanor Roosevelt and The Universal Declaration of Human Rights, Random House, New York.

Greer S. (2015), Is the Prohibition against Torture, Cruel, Inhuman and Degrading Treatment Really 'Absolute' in International Human Rights Law?, "Human Rights Law Review”, vol. 15, Issue 1.

Hug S., Lukács R. (2014), Preferences or blocks? Voting in the United Nations Human Rights Council, "The Review of International Organisations", vol. 9.

International Convention on the Elimination of All Forms of Racial Discrimination (1966), General Assembly of the United Nations, https://treaties.un.org/Pages/ViewDetails.aspx?src=IND\&mtdsg_ no $=I V-2 \&$ chapter $=4 \&$ lang $=$ en.

International Covenant on Civil and Political Rights (1966), General Assembly of the United Nations, https:/treaties.un.org/doc/publication/unts/volume\%20999/volume-999-i-14668-english.pdf.

International Covenant on Economic, Social and Cultural Rights (1966), General Assembly of the United Nations, https://treaties.un.org/Pages/ViewDetails.aspx?src=IND\&mtdsg_no=IV$3 \&$ chapter $=4 \&$ clang=_en.

Kuźniar R. (2008), Prawa człowieka. Prawo, instytucje, stosunki międzynarodowe, Wydawnictwo Naukowe Scholar, Warszawa.

Morsink J. (2017), The Universal Declaration of Human Rights and the Challenge of Religion, University of Missouri Press, Columbia.

Novak A. (2015), The International Criminal Court. An Introduction, Springer International Publishing AG, Cham.

Optional Protocol to the Convention against Torture and Other Cruel, Inhuman or Degrading Treatment or Punishment (2002), General Assembly of the United Nations, https://treaties.un.org/Pages/ ViewDetails.aspx?src=TREATY\&mtdsg_no=IV-9-b\&chapter=4\&clang=_en.

Osiatyński W. (2011), Prawa czlowieka i ich granice, Społeczny Instytut Wydawniczy "ZNAK", Kraków.

Rehman J. (2010), International Human Rights Law, Pearson Education Limited, London.

Resolution of the Economic and Social Council, 1235, XLII (1967), Economic and Social Council, http://hrlibrary.umn.edu/procedures/1235.html.

Resolution of the Economic and Social Council, 1296, XLIV (1968), Economic and Social Council, https://www.globalpolicy.org/component/content/article/177/31832.html.

Resolution of the Economic and Social Council, 1503, XLVIII (1970), Economic and Social Council, https://digitallibrary.un.org/record/84193.

Resolution of the General Assembly of the United Nations, A/RES/60/251 (2006), General Assembly of the United Nations, https://www.refworld.org/docid/4537814814.html.

Rome Statute of the International Criminal Court (1998), https://www.icc-cpi.int/nr/rdonlyres/ add16852-aee9-4757-abe7-9cdc7cf02886/283503/romestatuteng1.pdf.

Schabas W. (2011), An introduction in the International Criminal Court, Cambridge University Press, Camridge. 
Schabas W. (ed.) (2013), The Universal Declaration of Human Rights. The Travaux Préparatoires, Cambridge University Press, Cambridge.

Scheffer D. (2012), All the Missing Souls. A Personal History of the War Crimes Tribunals, Princeton University Press, Princeton.

Security Council Resolution S/RES/808 (1993), Security Council, http://unscr.com/en/resolutions/808.

Security Council Resolution, S/RES/955 (1994), Security Council, https://www.securitycouncilreport. org/un-documents/document/ij-sres955.php.

Spain Bradley A. S. (2019), Human Rights Racizm, "Harvard Human Rights Journal”, vol. 32.

The International Convention on Suppression and Punishment the Crime of Apartheid (1973), General Assembly of the United Nations, https://reaties.un.org/doc/Publication/UNTS/Volume $\% 20$ 1015/volume-1015-I-14861-English.pdf.

The Optional Protocol to the Convention on the Elimination of All Forms of Discrimination against Women (1999), General Assembly of the United Nations, https://webarchive.nationalarchives. gov.uk/20110310110723/http://www.justice.gov.uk/publications/docs/un-optional-protocolwomen.pdf.

The Second Optional Protocol to the International Covenant on Civil and Political Rights on the Abolition of the Death Penalty (1989), General Assembly of the United Nations, https://treaties. un.org/pages/ViewDetails.aspx? src=TREATY\&mtdsg_no=IV-12\&chapter=4.

United Nations Charter (1945), United Nations, https://treaties.un.org/doc/publication/ctc/uncharter. pdf.

Universal Declaration of Human Rights (1948), General Assembly of United Nations, https://www. un.org/en/udhrbook/pdf/udhr_booklet_en_web.pdf.

Universal Declaration of Human Rights (1948), United Nations, https://www.un.org/en/udhrbook/pdf/ udhr_booklet_en_web.pdf.

Weissbrodt D., Heilman Ch. (2011), Defining Torture and Cruel, Inhuman, and Degrading Treatment, "Law and Inequality", vol. 29.

Welling J. J. (2008), International Indicators and Economic, Social, and Cultural Rights, "Human Rights Quarterly", vol. 30.

William Sweet (ed.) (2003), Philosophical Theory and the Universal Declaration of Human Rights, University of Ottawa Press, Ottawa.

\section{Prawo do ladu społecznego i międzynarodowego na przykładzie działań ONZ}

\section{Streszczenie}

Przedmiotem artykułu są rozważania na temat prawa do ładu społecznego i międzynarodowego na przykładzie działań ONZ. Organizacja Narodów Zjednoczonych przyjęła wiele aktów dotyczących praw człowieka, takich jak deklaracje i prawnie wiążące prawa. Wniosek jest taki, że niekwestionowanym osiągnięciem Organizacji Narodów Zjednoczonych jest przyjęcie dużej liczby aktów prawnych, które gwarantują porządek społeczny i międzynarodowy. Mimo to nie ma skutecznych mechanizmów gwarantujących te prawa i szukania sprawiedliwości na forum międzynarodowym.

Słowa kluczowe: Organizacja Narodów Zjednoczonych, Powszechna Deklaracja Praw Człowieka, prawa człowieka, międzynarodowy wymiar sprawiedliwości w sprawach karnych 
